\title{
State of the Salmon: \\ Improving Predictions of Salmon Survival during a Period of Rapid Change
}

\author{
Sue C.H. Grant, Bronwyn L. MacDonald, David A. Patterson, Kendra A. Robinson, Jennifer L. Boldt, Keri \\ Benner, Jackie A. King, Lucas Pon, Chrys M. Neville, Joe A. Tadey, Mike Hawshaw, and Dan T. Selbie
}

\author{
Fisheries and Oceans Canada, Pacific Region, British Columbia, Canada
}

Keywords: salmon, productivity, abundance, trends, forecasts, Pacific, status, growth, climate change, survival, Fraser Sockeye, survival, integration, habitat change, ecosystem

The planet is warming. Earth's average land-ocean temperature has risen by close to $1{ }^{\circ} \mathrm{C}$ over the last century, with the most recent five years measuring as the warmest on record (Morice et al. 2012; Hartmann et al. 2013). Global climate change is already affecting Canadian Pacific salmon and their ecosystems, and these impacts will increase with further warming (IPCC 2014; White et al. 2016; Holsman et al. 2018; Bush and Lemmen 2019). In light of environmental change, it is critical that we track and understand how salmon are responding currently, and how they will respond to future change.

Information on climate-habitat conditions and Fraser River Sockeye salmon responses across life stages has been integrated annually since 2014. This work provides additional qualitative information on survival of Fraser River Sockeye survival to refine the pre-season quantitative return forecasts. This approach is being expanded to help predict the vulnerability of salmon populations to future climate and habitat change. Such vulnerability assessments results will support salmon management, recovery, and habitat restoration activities consider future change.

Quantitative forecasts of Fraser Sockeye returns by population are produced annually to support fisheries management processes (MacDonald and Grant 2012; DFO 2018, 2019). Challenges in determining factors that influence Fraser Sockeye survival (recruits-per-spawner) have resulted in very uncertain return forecasts. These factors act alone or cumulatively, and can vary by year and population, and in recent decades, salmon ecosystems have been experiencing unprecedented changes related to climate and habitat changes (Grant et al. 2019;

MacDonald et al. 2018).

An annual qualitative process was initiated by the State of the Salmon Program in 2014 to inform the quantitative forecast. This process integrates biological and environmental observations and data across research programs relevant to Fraser sockeye. This involves the collaboration of salmon and ecosystem experts working on the following life stages: upstream migration, spawners, egg stage, lake-rearing, downstream migration, and juvenile ocean-rearing. Observations during each of these stages are flagged if experts indicate they could affect survival at that particular stage. Individual observations are then integrated across life-stages to produce an overall prediction of survival.
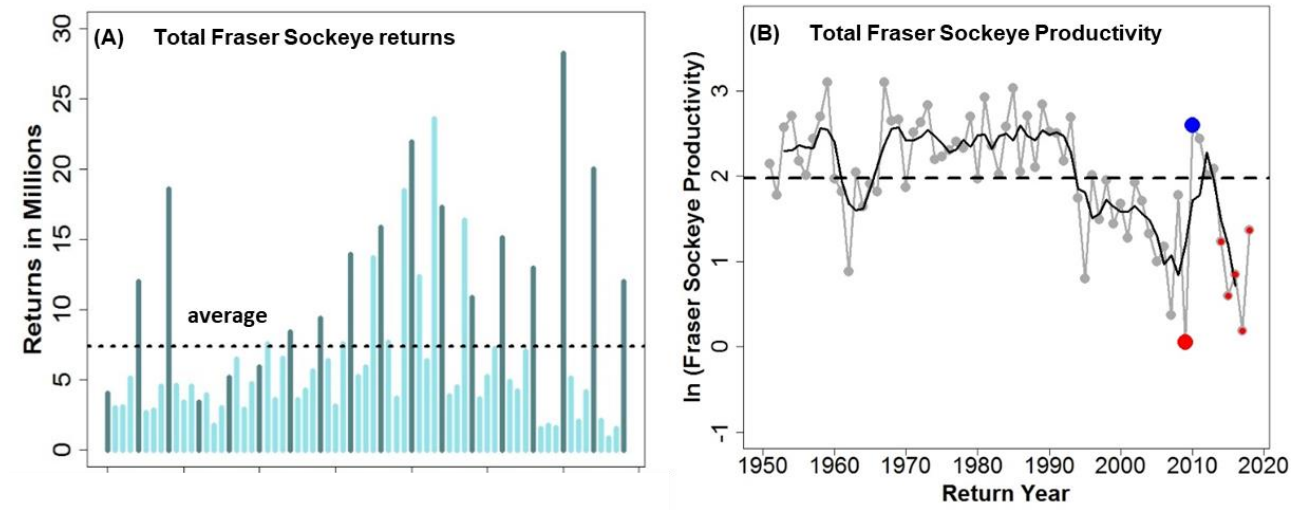

Fig. 1. (A) Total Fraser Sockeye annual returns (dark blue vertical bars for the 2018 cycle and light blue vertical bars for the three other cycles). Recent returns from 2016 to 2018 are preliminary, and 2018 (the last data point) is an in-season estimate only. (B) Total Fraser Sockeye productivity ( $\log _{\mathrm{e}}$ (returns/total spawner)) is presented up to the 2018 return year. The grey dots and lines represent annual productivity estimates and the black line represents the smoothed four year running average. For both figures, the dashed line is the time series average. 


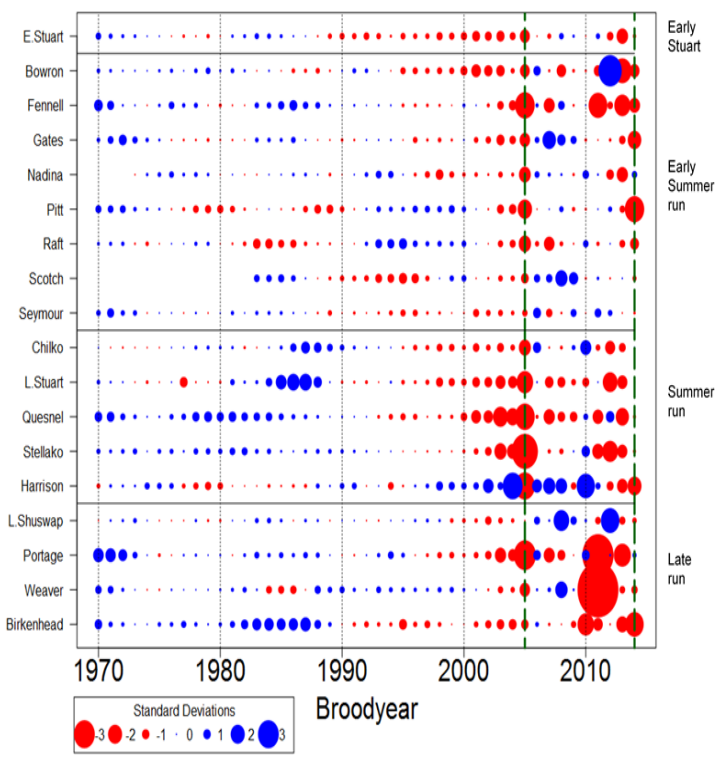

Fig. 2. Fraser Sockeye productivity (Ricker model residuals for all populations except Scotch, Seymour and Late Shuswap, which are Larkin residuals) up to the 2014 brood year (2018 return year) across 18 different populations and 4 different management groups (Early Stuart, Early Summer run, Summer run and Late run, named based on the migration timing of adults returning to their spawning grounds). Prior to the 2005 brood year, four year moving averages are plotted while annual estimates are provided for the more recent years. For the 2012 to 2014 brood years (2016 to 2018 return years), preliminary estimates of recruits by age are not yet available; preliminary in-season returns divided into population group using escapement proportions were applied to estimate recruits for each population. Both freshwater and marine factors contribute to the observed productivities. Red dots indicate below average productivity and blue dots indicate above average productivity. The smallest dots represent average annual productivity and the larger the diameter, the greater the deviation from average. The 2005 and 2014 brood years (2009 and 2018 return years) have been highlighted using a broken vertical green line.

The Fraser Sockeye aggregate has exhibited declines in total returns and survival in the last decade (Fig. 1). This trend was interrupted for a brief period from 2010 to 2013, when survival and returns improved to average. Poor returns and survival resumed from 2015 to 2018. Trends in aggregate Fraser sockeye returns and survival are largely determined by the populations that make up the greatest proportion of the total abundance in each year, namely Summer Run (e.g., Chilko), and Late Run populations (e.g., Late Shuswap on dominant cycle years).

Across individual Fraser Sockeye populations (Fig. 2), however, there can be considerable variability in survival. Examination of disaggregated data for the 19 populations shows that trends were synchronous across most populations in the early period of declining productivity and returns, suggesting that this was driven by broad-scale regional factors (Fig. 2). In more recent years, productivity has been asynchronous across Fraser Sockeye populations, indicating that local drivers, or unique population-specific factors, have contributed to the observed trends (Fig. 2). However, in the last two years, the return to poor productivity and returns has been largely synchronously poor across populations.
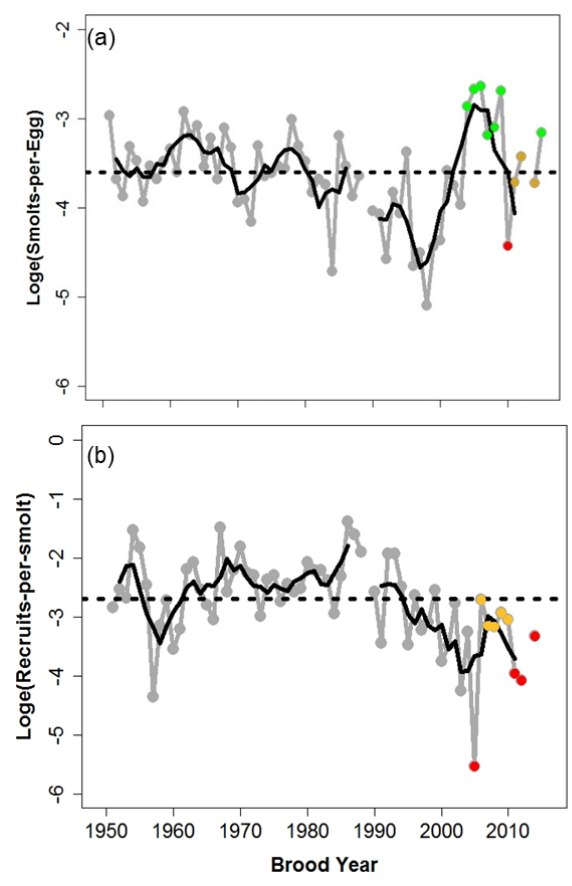

Fig. 3. (A) Chilko River Sockeye freshwater survival ( $\log _{\mathrm{e}}$ smolts-per-egg) and (B) 'marine' ( $\log _{\mathrm{e}}$ recruits-per-smolt) annual survival. The filled grey circles and grey lines are annual values and the black line is the smoothed four-year running average survival. Freshwater survival has generally increased in the past decade, with the notable exception of 2010), when poor survival was associated with density-dependent factors caused by the large escapements in this brood year. Marine survival has generally been below average for the past decade, and particularly low in the 2005 and last three brood years: 20112012 and 2014 (2013* is a gap in the time series). *Note: Chilko 'marine' survival includes a freshwater period during their downstream migration as smolts from the outlet of Chilko Lake to the Strait of Georgia, and their entire marine residence period. The horizontal dashed line indicates average survival.

*Note: High water levels prevented accurate counting of smolts in 2015, therefore freshwater and marine survival estimates are unavailable for the 2013 brood year (2017 return year). 
Total Fraser sockeye salmon survival is influenced by both freshwater and marine ecosystems. Fraser sockeye typically return to freshwater to spawn as four-year old fish, after spending their first two winters in freshwater, and their last two winters in the ocean. These populations use various freshwater and marine habitats throughout their life. Specifically, after their second winter in freshwater, most smolts leave their rearing lakes and migrate down the Fraser River to the Strait of Georgia. Most Fraser sockeye migrate north through the Strait of Georgia in approximately 40 days (Preikshot et al. 2012; Neville et al. 2016) and exit this system via the Johnstone Strait. Juveniles continue their northward migration along the continental shelf, and move into the Gulf of Alaska by their first winter at sea (Tucker et al. 2009). They subsequently spend one more winter in the marine environment before they return to their natal freshwater spawning grounds as adults.

Freshwater and marine survival data can help us potentially link survival with environmental conditions, by identifying the ecosystem in which trends in survival diverge across populations. This level of survival data is available for Chilko and Cultus sockeye, though the Cultus time series is confounded by low numbers of returns and high levels of hatchery enhancement. While both of these populations have exhibited declines in their marine survival (Fig. 3B for Chilko), trends in their freshwater survival diverge substantially, and drive the overall returns and statuses of these populations.

Differences in freshwater survival between Chilko and Cultus Sockeye populations is attributed, in part, to unique characteristics of their rearing lakes. Freshwater survival for Chilko sockeye has increased in the past decade (Fig. 3A for Chilko), and this population is healthy in comparison to most other Fraser sockeye in terms of overall survival and returns. Chilko sockeye rear in Chilko Lake, which is located in a remote, high alpine location, and is glacially fed with cool water. Cultus sockeye, in contrast, rear in a warm coastal lake that lies very close to a large urban centre (Vancouver, B.C.), and is subject to considerable agricultural and other sources of nutrient inputs (Putt et al. 2019), recreational use, and human development. Cultus Sockeye have exhibited a decline in freshwater survival, and this population is critically endangered, having negligible wild salmon production. Cultus survival data are not presented here, since this time series has many gaps and higher uncertainty. Chilko and Cultus emphasize differences in survival that can occur between populations, quite likely linked to differences in the suitability of the habitats they occupy.

In the last three return years, since 2016, many impacts of climate change have been observed in ecosystems that Fraser sockeye rely on (Schmitt et al. 2016; Holsman et al. 2018; Bush and Lemmen 2019; Grant et al. 2019). These impacts have been documented through the qualitative Fraser sockeye forecast process (MacDonald et al. 2018), and used to guide science recommendations on potential survival of returning cohorts of Fraser sockeye.

The warm 'Blob,' present in the Northeast Pacific Ocean from the latter half of 2013 to fall 2016, consisted of sea-surface-temperatures (SST) that were $3-5^{\circ} \mathrm{C}$ above seasonal averages and extended down to $100 \mathrm{~m}$ depths (Bond et al. 2015; Ross 2017). Climate modeling has shown that this marine heatwave can best be explained by human-caused warming (Walsh et al. 2018), suggesting that these events will become more frequent, and longer lasting in the future (Smale et al. 2019). The recent warming had profound effects on marine food webs, shifting zooplankton composition at the base of the salmon food web towards less nutritious, southern species (Galbraith and Young 2017). Detailed annual scientific information is compiled on the Northeast Pacific Ocean through DFO's State of the Pacific Ocean reporting process (Chandler et al. 2016, 2017, 2018).

British Columbia air temperatures have also been increasing across all seasons in recent decades (Pike et al. 2008; White et al. 2016). High temperatures in freshwater are particularly problematic in the Fraser River, where they now regularly exceed critical thermal limits for salmon during summer months, falling above $18-20^{\circ} \mathrm{C}($ Eliason et al. 2011; Martins et al. 2012; MacDonald et al. 2018). Patterns of stream flow are changing throughout BC/Yukon as snowpacks melt earlier in spring, causing early freshets (Pike et al. 2008; Pike et al. 2010a, 2010b). There are examples where salmon smolt outmigrations have concurrently shifted earlier (MacDonald et al. 2018). Freshwater impacts of climate change will vary with local conditions across BC and the Yukon and will interact with other human induced landscape changes. For many salmon populations, these impacts will have negative effects on condition and/or survival, which will act cumulatively across their life stages (McDaniels et al. 2010; Healey 2011).

Through the State of the Salmon qualitative forecast process, experts integrated observations and data on anomalously warm conditions, ecosystem changes, and expected or reported salmon responses across the various life-stages, prior to the returns of Fraser sockeye for 2017-2019 (MacDonald et al. 2018). In each of these years, below average survival was predicted as a result of this integration process. Consistent with this advice, Fraser sockeye survival was below average in 2017 and 2018 (Figs. 1 and 2), providing early validation for this expertjudgement process. Preliminary return numbers and productivity in 2019 were the lowest on record.

Also notable in 2019, a major landslide was discovered in June 2019 on the Fraser River at Big Bar, near Lillooet, B.C. This landslide has effectively blocked passage of all Fraser sockeye populations that spawn upstream 
of this location. This blockage lies upstream of the Thompson system, but downstream of tributaries for major populations like Chilko, Quesnel, Early and Late Stuart, and Nadina, Stellako, and Bowron. At the time of writing this report, mitigation of the slide is being attempted, though significant impacts on the survival of fish spawning upstream of this slide are anticipated in 2019.

DFO's State of the Salmon Program is expanding on lessons learned from the qualitative forecasting process for Fraser sockeye, due to its success in guiding predictions, and in fostering collaboration and integration of science and expert judgement. Leads from this program are coordinating an approach for a broader group of scientists to conduct vulnerability assessments for Canadian Pacific Salmon, in light of climate and habitat change. This work is essential to inform management actions and ensure the best possible outcomes for salmon in a changing climate. It is a critical time in human history, when biodiversity losses are occurring at an unprecedented rate (WWF 2017; IPBES 2018). However, mitigation is still possible as long as we are able to prepare accordingly, and capitalize on our collective knowledge.

\section{REFERENCES}

Bond, N.A., M.F., Cronin, H. Freeland, and N. Mantua. 2015. Causes and impacts of the 2014 warm anomaly in the NE Pacific. Geophys. Res. Lett. 42(9): 3414-3420. doi:10.1002/2015GL063306.

Bush, E., and D.S. Lemmen. (Editors). 2019. Canada's changing climate report. Government of Canada, Ottawa, Ontario. (Available at www.ChangingClimate.ca/CCCR2019)

Chandler, P.C., S.A. King, and J. Boldt. (Editors). 2017. State of the physical, biological and selected fishery resources of Pacific Canadian marine ecosystems in 2016. Can. Tech. Rep. Fish. Aquat. Sci. 3225. vi +243 pp.

Chandler, P.C., S.A. King, and J. Boldt. (Editors). 2018. State of the physical, biological and selected fishery resources of Pacific Canadian Marine Ecosystems in 2017. Can. Tech. Rep. Fish. Aquat. Sci. 3266. viii + 245 pp.

Chandler, P.C., S.A. King, and R.I. Perry. (Editors). 2016. State of the physical, biological and selected fishery resources of Pacific Canadian marine ecosystems in 2015. Can. Tech. Rep. Fish. Aquat. Sci. 3179 pp.

DFO. 2018. Pre-season run size forecasts for Fraser River sockeye salmon (Oncorhynchus nerka) in 2018. Can. Sci. Advis. Sec. Sci. Resp. 2018/034. 70 pp.

DFO. 2019. Pre-season run size forecasts for Fraser River Sockeye (Oncohrynchus nerka) and Pink (O. gorbuscha) Salmon in 2019. DFO Fraser Stock Assessment Technical Memo. 55 pp.

Eliason, E.J., T.D. Clark, M.J. Hague, L.M. Hanson, Z.S. Gallagher, K.M. Jeffries, M.K. Gale, D.A. Patterson, S.G. Hinch, and A.P. Farrell. 2011. Differences in thermal tolerance among sockeye salmon populations. Science332(6025): 109-112. doi:10.1126/science.1199158.

Galbraith, M., and K. Young. 2017. Zooplankton along the B.C. continental margin 2016. In State of the Physical, Biological and Selected Fishery Resources of Pacific Canadian Marine Ecosystems in 2016. Edited by P.C. Chandler, S.A. King, and J.L. Boldt. Can. Tech. Rep. Fish. Aquat. Sci. 3225. pp. 67-75.

Grant, S.C.H., MacDonald, B.L., and Winston, M.L. 2019. State of the Canadian Pacific Salmon: Responses to Changing Climate and Habitats. Can. Tech. Rep. Fish. Aquat. Sci. 3332: ix + 50 pp.

Hartmann, D.L., A.M.G. Klein Tank, M. Rusticucci, L.V. Alexander, S. Brönnimann, Y. Charabi, F.J. Dentener, E.J. Dlugokencky, D.R. Easterling, A. Kaplan, B.J. Soden, P.W. Thorne, M. Wild, and P.M. Zhaj. 2013. Observations: atmosphere and surface. In Climate change 2013 the physical science basis: Contribution of Working Group I to the Fifth Assessment Report of the Intergovermental Panel on Climate Change. Edited by T.F. Stocker, D. Qin, and G.K. Plattner. pp. 159-254.

Healey, M. 2011. The cumulative impacts of climate change on Fraser River sockeye salmon (Oncorhynchus nerka) and implications for management. Can. J. Fish. Aquat. Sci. 68(4): 718-737. doi:10.1139/f2011-010.

Holsman, K., A. Hollowed, I. Shin-Ichi, S. Bograd, E. Hazen, J. King, F. Mueter, and R.I. Perry. 2018. Climate change impacts, vulnerabilities and adaptations: North Pacific and Pacific Arctic marine fisheries. In Impacts of climate change on fisheries and aquaculture: synthesis of current knowledge, adaptation and mitigation options. Edited by M. Barange, T. Bahri, M.C.M. Beveridge, K.L. Cochrane, S. Funge-Smith, and F. Poulain. FAO Fisheries and Aquaculture Technical Paper, No. 627. FAO, Rome. pp. 113-138.

IPBES. 2018. The regional assessment report on biodiversity and ecosystem services for the Americas. Edited by J. Rice, C.S. Seixas, M.E. Zaccagnini, M. Bedoya-Gaitán, and N. Valderrama. Secretariat of the Intergovernmental Science-Policy Platform on Biodiversity and Ecosystem Services, Bonn, Germany. pp. 656. 
IPCC. 2014. Climate Change 2014: Synthesis Report. Contribution of Working Groups I, II, and III to the Fifth Assessment Report of the Intergovernmental Panel on Climate Change. Edited by R.K. Pachauri and L. Meyer. IPCC, Geneva, Switzerland. pp. 151.

MacDonald, B.L., and S.C.H. Grant. 2012. Pre-season run size forecasts for Fraser River sockeye salmon (Oncorhynchus nerka) in 2012. Can. Sci. Advis. Sec. Res. Doc. 2012/011: v + 64.

MacDonald, B.L., S.C.H. Grant, D.A. Patterson, K.A. Robinson, J.L. Boldt, K. Benner, C.M. Neville, L. Pon, L., J.A. Tadey, D.T. Selbie, and M.L. Winston. 2018. State of the Salmon: informing the survival of Fraser sockeye returning in 2018 through life cycle observations. Can. Tech. Rep. Fish. Aquat. Sci. 3271: v + 53.

Martins, E.G., S.G. Hinch, Patterson, D.A., Hague, M.J., Cooke, S.J., Miller, K.M., Robichaud, D., English, K.K., and Farrell, A.P. 2012. High river temperature reduces survival of sockeye salmon (Oncorhynchus nerka) approaching spawning grounds and exacerbates female mortality. Can. J. Fish. Aquat. Sci. 69: 330-342. doi:10.1139/F2011-154.

McDaniels, T., S. Wilmot, M. Healey, and S. Hinch. 2010. Vulnerability of Fraser River sockeye salmon to climate change: a life cycle perspective using expert judgments. J. Environ. Manag. 91(12): 2771-2780. doi:10.1016/j.jenvman.2010.08.004.

Morice, C.P., J.J. Kennedy, N.A. Rayner, and P.D. Jones. 2012. Quantifying uncertainties in global and regional temperature change using an ensemble of observational estimates: The HadCRUT4 data set. J. Geophys. Res. Atmos. 117(D8): 1-22. doi:10.1029/2011JD017187.

Neville, C.E., S. Johnson, T. Beacham, T. Whitehouse, J. Tadey, and M. Trudel. 2016. Initial estimates from an integrated study examining the residence period and migration timing of juvenile Sockeye Salmon from the Fraser River through coastal waters of British Columbia. N. Pac. Anadr. Fish Comm. Bull. 6(1): 45-60. doi:10.23849/npafcb6/45.60.

Pike, R.G., T.E. Redding, R.D. Moore, R.D. Winkler. and K.D. Bladon (Editors). 2010a. Compendium of forest hydrology and geomorphology in British Columbia, Volume 1 of 2., B.C. Min. For. Range, For. Sci. Prog., Victoria, B.C. and FORREX Forum for Research and Extension in Natural Resources, Kamloops, B.C., Land Manag. Handb. 66. pp. 1-400.

Pike, R.G., T.E. Redding, R.D. Moore, R.D. Winkler, and K.D. Bladon (Editors). 2010b. Compendium of forest hydrology and geomorphology in British Columbia, Volume 2 of 2., B.C. Min. For. Range, For. Sci. Prog., Victoria, B.C. and FORREX Forum for Research and Extension in Natural Resources, Kamloops, B.C., Land Manag. Handb. 66. pp. 401-806.

Pike, R.G., D.L. Spittlehouse, K.E. Bennett, V.N. Egginton, P.J. Tschaplinski, T.Q. Murdock, and A.T. Werner. 2008a. Climate Change and Watershed Hydrology: Part I - Recent and Projected Changes in British Columbia. Streamline Watershed Manag. Bull. 11(2): 1-7.

Preikshot, D., R.J. Beamish, R.M. Sweeting, C.E. Neville, and T.D. Beacham. 2012. The residence time of juvenile Fraser River sockeye salmon in the Strait of Georgia. Mar. Coast. Fish. Dyn. Manag. Ecosyst. Sci. 4(1): 438449. doi:10.1080/19425120.2012.683235.

Putt, A.E., E.A. Macisaac, H.E. Herunter, A.B. Cooper, and D.T. Selbie. 2019. Eutrophication forcings on a periurban lake ecosystem: context for integrated watershed to airshed management. PLoS One: 14(7): e0219241. doi:10.1371/journal.pone.0219241.

Ross, T. 2017. La Niña, the blob and another warmest year. In State of the physical, biological and selected fishery resources of Pacific Canadian marine ecosystems in 2016. Edited by P.C. Chandler, S.A. King, and J.L. Boldt. Can. Tech. Rep. Fish. Aquat. Sci. 3225. pp. 30-34.

Schmitt, C.K., C. Wildner, and B. Drossel. 2016. Noisy predator-prey model explains oscillation patterns in sockeye salmon data. J. Theor. Biol. 389: 198-205.

Smale, D.A., T. Wernberg, E.C.J.J. Oliver, M. Thomsen, B.P. Harvey, S.C. Straub, M.T. Burrows, L.V. Alexander, J.A. Benthuysen, M.G. Donat, M. Feng, A.J. Hobday, N.J. Holbrook, S.E. Perkins-Kirkpatrick, H.A. Scannell, A. Sen Gupta, B.L. Payne, and P.J. Moore. 2019. Marine heatwaves threaten global biodiversity and the provision of ecosystem services. Nat. Clim. Chang. 9(4): 306-312. doi:10.1038/s41558-019-0412-1.

Streicker, J. 2016. Yukon Climate Change Indicators and Key Findings in 2015. Northern Climate ExChange, Yukon Research Centre, Yukon College. 84 pp.

Tucker, S., M. Trudel, D.W. Welch, J.R. Candy, J.F.T. Morris, M.E. Thiess, C. Wallace, D.J. Teel, W. Crawford, E.V. Farley, and T.D. Beacham. 2009. Seasonal stock-specific migrations of juvenile sockeye salmon along the west coast of North America: implications for growth. Trans. Am. Fish. Soc. 138(6): 1458-1480. doi:10.1577/T08-211.1.

Walsh, J.E., R.L. Thoman, U.S. Bhatt, P.A. Bieniek, B. Brettschneider, M. Brubaker, S. Danielson, R. Lader, F. Fetterer, K. Holderied, K. Iken, A. Mahoney, M. McCammon, and J. Partain. 2018. The high latitude marine 
heat wave of 2016 and its impacts on Alaska. Bull. Am. Meteorol. Soc. 99(1): S39-S43. doi:10.1175/BAMSD-17-0105.1.

White, T., J. Wolf, F. Anslow, and A. Werner. 2016. Indicators of climate change for British Columbia: Update 2016. Victoria, B.C.

WWF. 2017. Living Planet Report Canada: A National Look at Wildlife Loss. WWF-Canada, Toronto, Ontario. $64 \mathrm{pp}$. 